\title{
VLIV SVĚTELNÉHO ZDROJE BRZDOVÝCH SVĚTEL NA REAKČNÍ DOBU ŘIDIČE
}

\section{INFLUENCE OF BRAKE LIGHT LIGHT SOURCE ON DRIVER REACTION TIME}

\author{
Petr Jilek ${ }^{1,}$, Luboš Vrábel ${ }^{2}$
}

\begin{abstract}
Abstrakt
Příspěvek se zabývá zjištěním vlivu typu světelného zdroje brzdových světel automobilu na reakční dobu řidiče. V př́spěvku je měřena reakční doba řidiče v podobě sešlápnutí brzdového pedálu v závislosti na rozsvícení brzdových světel u vodícího vozidla. Vyhodnocení měření spočívá ve vzájemném porovnání fázového posunu mezi signálem brzdových světel prvního vozidla a signálem brzdových světel u druhého vozidla. Experimentální měření bylo realizováno pro pět osob a to při použití klasické žárovky a následně LED diody u brzdových světel prvního vozidla. Z naměřených průběhů se potvrdilo, že reakční doba řidiče je závislá na mnoha faktorech, kdy významnou roli hraje i zdroj a intenzita světla brzdových světel. Současně má vliv na reakční dobu i činnost či nečinnost zadních obrysových světel. S jejich aktivací se reakční doba řidiče následného vozidla prodlužuje.
\end{abstract}

Klíčová slova reakční doba, automobil, brzdové světlo, bezpečnost

Summary The paper deals with finding out the influence of the type of light source of car brake lights on the reaction time of the driver. The paper measures the reaction time of the driver in the form of depressing the brake pedal depending on the lighting of the brake lights on the driving vehicle. The evaluation of the measurement consists in a mutual comparison of the phase shift between the brake light signal of the first vehicle and the brake light signal of the second vehicle. The experimental measurement was performed for five people using a classic light bulb and then an LED diode at the brake lights of the first vehicle. From the measured waveforms, it was confirmed that the driver's reaction time depends on many factors, where the source and intensity of the brake lights also play an important role. At the same time, it affects the reaction time and the operation or inactivity of the rear position lamps. With their activation, the reaction time of the driver of the succeeding vehicle is extended.

Keywords reaction time, car, brake light, safety

\section{1 ÚVOD}

V současné době, kdy se v automobilové technice objevují stále nové materiály a konstrukční metody, je třeba brát v potaz také jejich vliv na chování řidiče okolních vozidel. Důležitým prvkem aktivní bezpečnosti silničního vozidla je jeho osvětlení. Důležité je nejen aby řidič viděl a mohl se takto orientovat v silničním

\footnotetext{
${ }^{1}$ Univerzita Pardubice, Dopravní fakulta Jana Pernera, Výukové a výzkumné centrum v dopravě, Studentská 95, 53210 Pardubice, Česká republika 2 Univerzita Pardubice, Dopravní fakulta Jana Pernera, Katedra dopravních prostředků a diagnostiky, Studentská 95, 53210 Pardubice, Česká republika korespondenční autor: petr.jilek@upce.cz
} 
provozu. Ale neméně důležitým aspektem je také, aby byl viděn. Tato skutečnost platí především v oblasti, kdy se jedná o mimořádnou situaci, jako je změna jízdního směru anebo snížení rychlosti. Tedy důležitým aspektem je viditelnost směrových a brzdových světel. Velká část ze všech nehod je způsobena právě nedodržením bezpečné vzdálenosti, kdy řidič nestačil včas a správně zareagovat na vzniklou situaci v silničním provozu. Z hlediska bezpečnosti silničního provozu je třeba se zaměřit na opatření, které zajistí dodržování bezpečné vzdálenosti, a které zkrátí reakční dobu řidič (Kleprlík, 2020).

U současných vozidel, kdy se řeší design vozidel je silným nástrojem tvar předních světlometů a zadních svítilen. S novými světelnými technologiemi již zadní svítilny nemají jednoduché provedení, ale jedná se o 3D prostorové tvary. Proto je možné, aby brzdová světla byla součástí zadní svítilny, a přesto plnili svoji funkci.

\section{MODERNÍ ŘEŠENÍ BRZDOVÝCH SVĚTEL}

V následujícím textu pojednáváme o nové technologii v konstrukci brzdových světel vedoucí ke zvýšení bezpečnosti silničního provozu a k omezení materiálních škod a škod na zdraví ostatních účastníků. Současné zdroje světla LED jsou stále častěji nahrazovány technologií OLED.

Dvoustupňové brzdové světlo má činnou plochu rozdělenu na dvě části. Pokud je brzdné zpomalení nižší než $5 \mathrm{~ms}^{-2}$ rozsvítí se jen jedna část, jelikož se jedná o běžné brzdné zpomalení. Při zvýšení brzdného zpomalení nad $5 \mathrm{~ms}^{-2}$ se rozsvítí i druhá část brzdového světla. Případně k jeho rozsvícení dochází i při aktivaci systému ABS. Takto je vyšší intenzitou světelného toku signalizováno panické brzdění, tak aby řidiči jedoucí za daným vozidlem byly intenzivně upozorněny na brzdění (Vlk, 2006).

Adaptivní brzdová světla při brzdění blikají 4x vyšší frekvencí, než je tomu u světel směrových. Tento stav slouží kintenzivnějšímu upozornění ostatních řidičů na změnu jízdní situace. Alternativou k předešlému je možnost, že při panickém brzdění se brzdová světla rozsvítí a k nim se přidají varovná světla.

V reálných podmínkách je patrné, že brzdová světla nejsou viditelná pro vozidlo jedoucí v závěsu, proto automobilka Ford testuje technologii radiového signálu. Technologie spočívá v tom, že brzdící vozidlo vysílá radiový signál o definovaných parametrech a vozidlo v závěsu po identifikaci tohoto signálu řidiče varuje rozblikáním signálního světla n panelu přístrojů. Takto je řidič upozorněn o brzdícím vozidle, které je mimo jeho dohledovou vzdálenost (Autoforum.cz, 2019). Princip systému je patrný na Obr. 1.

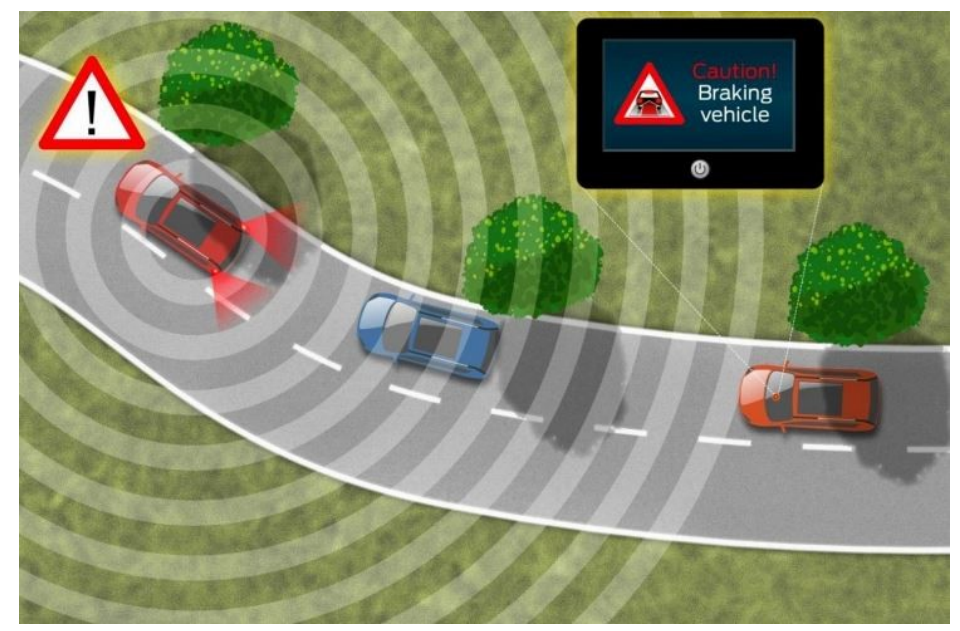

Obr. 1 Brzdová světla s radiovým signálem (Autoforum.cz, 2019)

Laserové brzdové světlo generuje optický signál laserovou diodou. Tato je mírně skloněna na vozovku a za dobrých světelných podmínek vykresluje na vozovku červenou linku definující bezpečnou vzdálenost za vozidlem. Za deště či v mlze světelný paprsek dopadá na kapičky vlhkosti a tím se stává viditelný. Takto je v prostoru pod brzdovým světlem vykreslován trojúhelník. 


\section{REAKČNÍ DOBA ŘIDIČE}

Reakční doba řidiče je dána fyziologickou podstatou člověka jako živého organismu, proto nemůže být nekonečně krátká. Její délka je dána morální integritou a aktuálním psychologickým rozpoložením. Př́́padně omamnými a návykovými látkami v těle člověka (Borecký, 2018; Osmančík, 2017). Za reakční dobu řidiče je možné považovat dobu, která je nutná $\mathrm{k}$ tomu, aby řidičův biologický systém zareagoval na podnět, který se nachází v zorném poli řidiče, a to i v takových případech, kdy se jedná o podnět náhlý a neočekávaný.

Optická reakce je dána okamžikem postřehnutí objektu, který není v zorném poli řidiče. Zrakové vnímání je zásadní při řízení vozidla. Řidič jím získává okolo 90 \% všech informací. Doba optické reakce se pohybuje v rozmezí 0-0,7 sekundy a závisí na velikosti úhlové odchylky podnětu od směru pohledu řidiče (Borecký, 2018).

Psychická reakce je definována jako časový interval potřebný řidiči k rozpoznání a vyhodnocení podnětu. Jedná se o dobu, která se mění v závislosti na složitosti situace, požití návykové a psychotropní látky a únavě řidiče. Reakce je také značně ovlivněna v pozitivním směru zkušenostmi a očekáváním možné situace. Negativní vliv má vzniklá situace, která má více řešení. Zde řidič vyhodnocuje nastalou situaci a dle získaných podnětů se rozhoduje, jaký úkon udělá. Délka psychické reakce je 0,2 - 0,6 sekundy (Borecký, 2018; Kleprlík, 2020; Zikmund, 2006).Error! Reference source not found.

Svalová reakce je také dána biologickou podstatou lidského těla a jedná se reakcí těla na zjištěný podnět. Je významně ovlivněna tréninkem a trajektorií pohybu. U řidiče se jedná o časový interval mezi ukončením psychické reakce až po okamžik, v našem případě, kdy se řidič dotkne brzdového pedálu. Interval svalové reakce je přibližně 0,2 sekundy (Borecký, 2018; Kleprlík, 2020).

Členění reakční doby mezi automobilem a řidičem je možné realizovat dle mnoha hledisek, které jsou blíže zpracovány v Jilek (2018), Bradáč (1997), Štěrba (2013). Z pohledu bezpečnosti silničního provozu je třeba reakční době řidiče věnovat vysokou pozornost. Každé prodloužení reakční doby je nežádoucí a prodlužuje tak celkovou dráhu potřebnou k bezpečnému zastavení vozidla. Proto se využívá asistenčních systémů. Jako prvky, které zkracují reakční dobu řidiče, se u současných vozidel začínají stále více prosazovat asistenční systémy v podobě aktivních tempomatů ACC (Suzuki, 2013), systémy nočního vidění (Autorevue.cz, 2019), systém panického brzdění (Sorniotti, 2016).

\section{EXPERIMENTÁLNÍ MĚŘENÍ}

Experimentální měření jsme realizovali na stojících vozidlech. Tyto byla umístěna v krytých prostorách laboratoří Výukového a výzkumného centra v dopravě Univerzity Pardubice. Vedoucí vozidlo bylo viditelné z druhého vozidla. Osvětlení místa měření bylo konstantní. Stojící vozidla jsme volili záměrně, aby řidič při experimentu nebyl ovlivněn rušivými vlivy okolí. Aktuální podmínky z realizace experimentu jsou patrné na Obr. 2. Pro experiment byly vybrány vozy Škoda Rapid a Škoda Superb. Vedoucí vozidlo, které inicializovalo reakční podnět, byla Škoda Rapid.

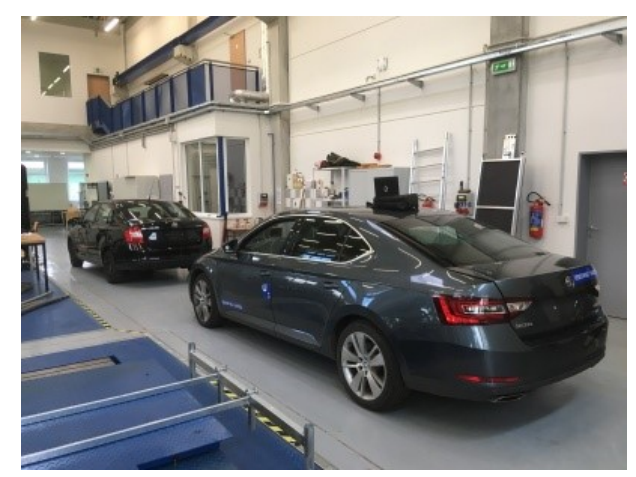

Obr. 2 Realizace experimentu 


\subsection{Měřené datové průběhy:}

- Brzdový signál $B S$ - je nositelem informace o počátku brzdění u testované osoby - náběžná hrana. Jedná se o obdélníkový signál, který svou sestupnou hranou definuje ukončení procesu působení na brzdový pedál testovanou osobou.

- Optický signál $O S$ - je definován počátkem působení na brzdový pedál u vodícího vozidla. Vodícím vozidlem je automobil, na jehož rozsvícení brzdových světel reaguje testovaná osoba ve druhém vozidle.

- Reakční doba řidiče $R D \check{R}$ - jsme vypočetli ze vzájemného fázového posunu mezi měřenými signály dle vztahu (1) z naměřeného brzdového a optického signálu. Každému signálu odpovídá konkrétní časový interval.

$$
R D \check{\mathrm{R}}=B S(t)-O S(t) .
$$

V okamžiku sešlápnutí brzdového pedálu vedoucího vozidla dojde $\mathrm{k}$ aktivaci brzdového světla. Tento představuje jednoduchý optický podnět pro testovanou osobu. Měřící ústředna (Obr. 4) (bližší specifikace jsou uvedené v Zikmund, 2006) zaznamená optický signál OS vedoucího vozidla skokovou změnou vstupního parametru. V okamžiku sešlápnutí brzdového pedálu u druhého vozidla dojde kaktivaci brzdového světla vozidla s testovanou osobou a zároveň dojde k rozpojení měřícího relé. Měřící ústředna zaznamenána skokovou změnu vstupního parametru. Tímto se získává brzdový signál $B S$ vozidla $\mathrm{s}$ testovanou osobou. Průběh Optického a brzdového signálu je graficky znázorněn na Obr. 3. Možné logické úrovně průběhů vyhodnocovaných signálů jsou schematicky zobrazeny na Obr. 4.

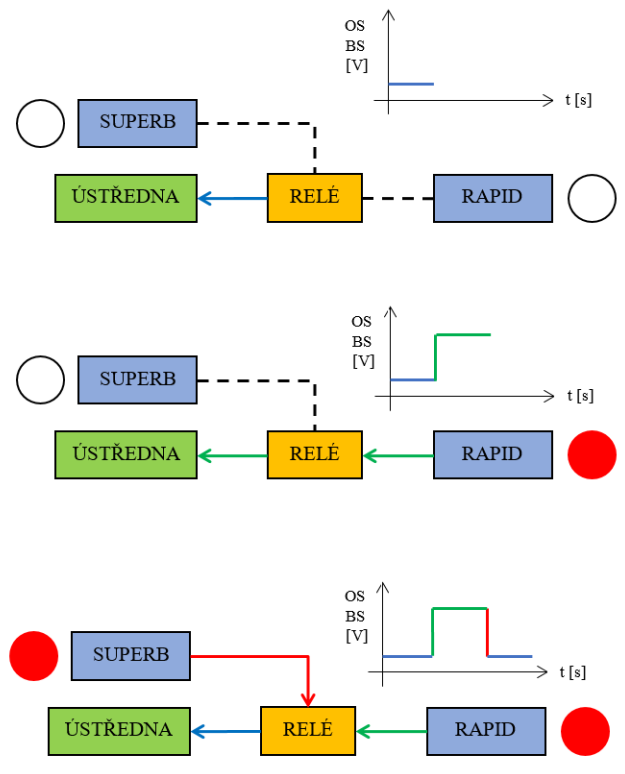

Obr. 3 Logika měřených průběhů
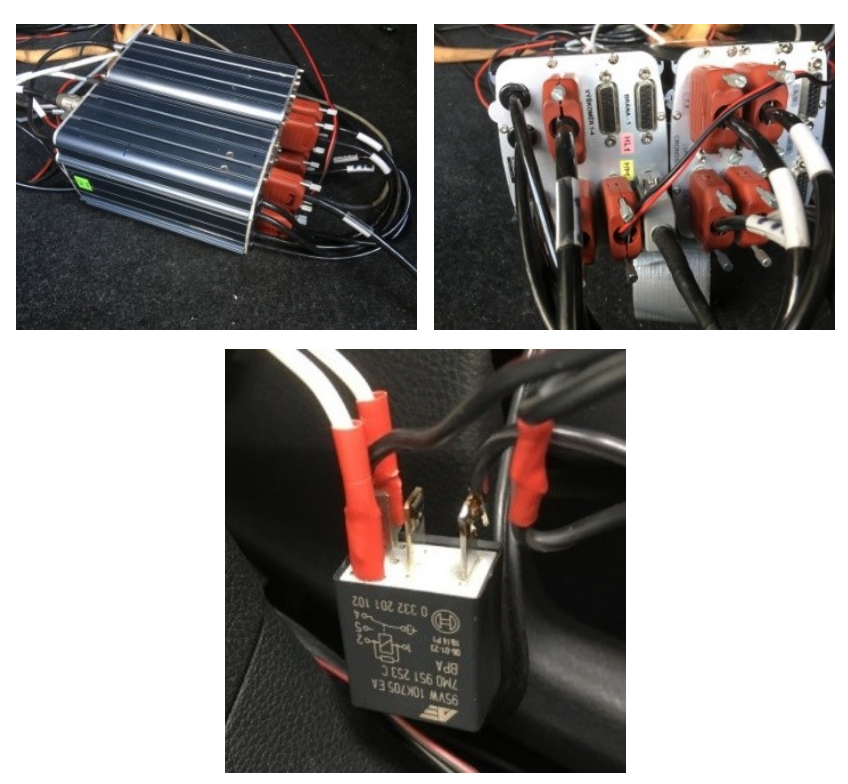

Obr. 4 Použitý měřící systém

\subsection{Zdroj světelného toku}

Jako první zdroj světelného toku jsme volili originální žárovku v provedení P 21/4 W. Za její alternativu jsme použili LED zdroj světelného toku. Tato byla bez potřebné homologace pro provoz na pozemních komunikacích.

Stanovení intervalu plného svitu světelného zdroje jsme realizovali za pomoci videozáznamu. Jedná se o deset měření pro klasický světelný zdroj a následně stejný počet měření pro LED. Vyhodnocení potřebného náběhu světelného toku jsme realizovali pomocí rozfázování záznamu. Kdy za počátek rozsvícení byl volen poslední snímek, kde je světelný tok nulový. Za plný svit světelného zdroje jsme vybrali první snímek, kde u následujícího již nedošlo k nárůstu intenzity světelného toku. Dle výsledků 
z měření je patrné, že světelný zdroj LED dosáhne plného svitu za 0,033 s a klasická žárovka za 0,2 s, tak jak je patrné na Obr. 5 .

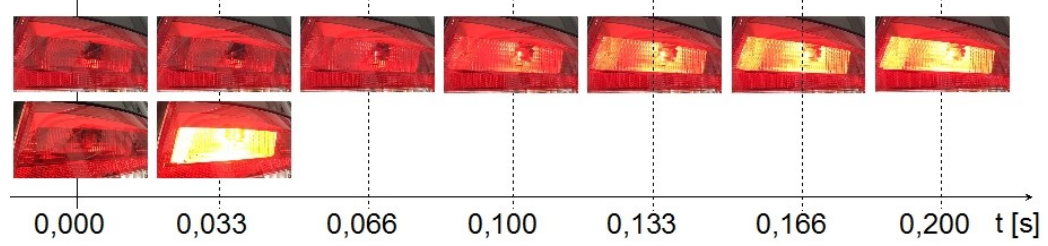

Obr. 5 Nárůst světelného toku klasická žárovka/LED

\subsection{Podmínky realizace experimentu}

Měření reakční doby probíhalo v laboratoři při umělém a částečně denním osvětlení. Experimentálního měření se účastnily 4 muži a jedna žena. Testované osoby byly ve věkovém rozmezí $27-44$ let. Vedoucí vozidlo se nacházelo před druhým vozidlem s testovanou osobou ve vzdálenosti 2,5 metru. Optickým podnětem byla zvolena soustava zadních brzdových světel vedoucího vozidla. Střední brzdová svítilna s LED zdrojem světelného toku by negativně znehodnotily výstup měření. Proto byla na vedoucím vozidla deaktivována. Vedoucí vozidlo $\mathrm{v}$ nahodilých časových intervalech rozsvěcovalo brzdová světla po stanovenou dobu. Takto vznikly reakční podněty pro testovanou osobu ve druhém vozidle. Úkolem testovaných osob bylo sešlápnout a držet pedál akcelerátoru v maximální poloze. Takto jsme eliminovali možnou připravenost pravé nohy testované osoby na sešlápnutí brzdového pedálu. V okamžiku zaregistrování rozsvícení brzdových světel vedoucího vozidla musela testovaná osoba sešlápnout brzdový pedál v co nejkratším možném intervalu.

Experiment jsme realizovali ve dvou variantách, kde vzájemný rozdíl je v tom, že ve druhém případě byla oproti první sadě měření rozsvícena zadní obrysová světla, čímž testovací podnět byl méně výrazný, než při vypnutých obrysových světlech.

\section{ZPRACOVÁNÍ A VYHODNOCENÍ DAT EXPERIMNTU}

Pro stanovení reakční doby u testovaných osob jsme použili medián $\tilde{x}$, vypočtený dle vztahu 2.

$$
\tilde{x}=\frac{x_{\left(\frac{N}{2}\right)}+x_{\left(\frac{N}{2}+1\right)}}{2},
$$

kde:

$$
\begin{aligned}
& N \quad \text { - počet všech hodnot, } \\
& x_{\left(\frac{N}{2}\right)} \text { - první hodnota s indexem určujícím pozici v rostoucí posloupnosti hodnot, } \\
& x_{\left(\frac{N}{2}+1\right)} \text { - druhá hodnota s indexem určujícím pozici v rostoucí posloupnosti hodnot. }
\end{aligned}
$$

Výsledná reakční doba pro celou skupinu testovaných osob je uvedena v Tab. 1.

Tab. 1 Reakční doba skupiny testovaných osob

\begin{tabular}{lccc}
\hline \multicolumn{1}{c}{ reakční doba [s] } & $\begin{array}{c}\text { světelný } \\
\text { zdroj } \\
\text { źárovka }\end{array}$ & $\begin{array}{c}\text { světelný } \\
\text { zdroj led }\end{array}$ & delta \\
\hline $\begin{array}{l}\text { zhasnutá zadní obrysová světla } \\
\text { rozsvícená zadní obrysová } \\
\text { světla }\end{array}$ & 0,5925 & 0,5600 & 0,0325 \\
& 0,6087 & 0,5725 & 0,0363 \\
\hline
\end{tabular}

Grafické zobrazení výsledků z měření je patrné z Obr. 6, 7 a 8. 


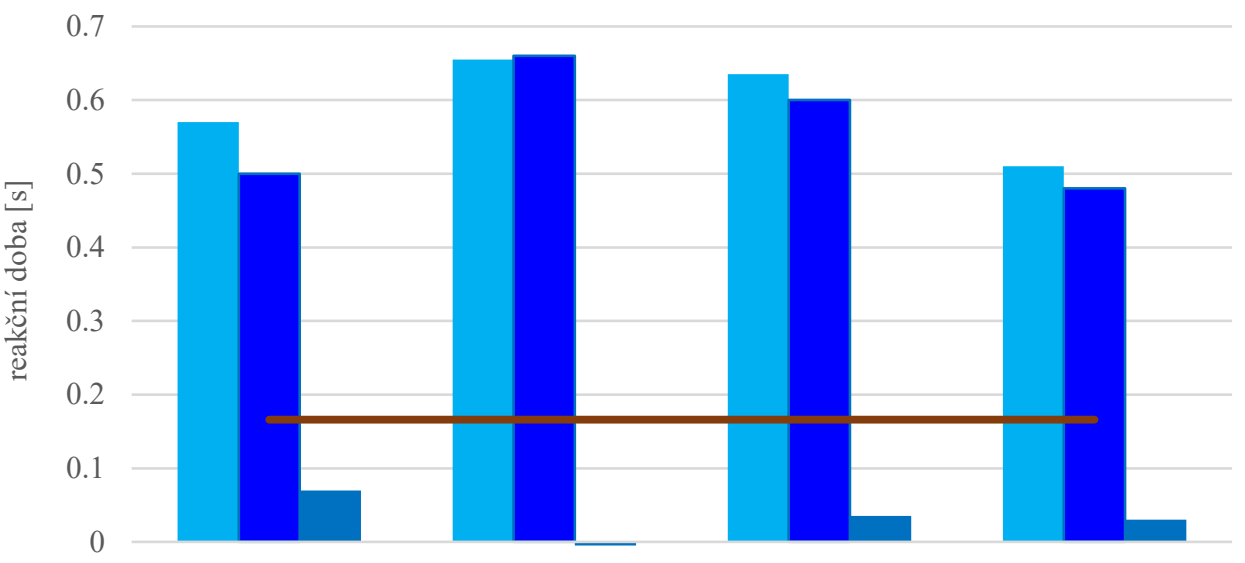

\begin{tabular}{|l|c|c|c|c|}
\multicolumn{1}{c|}{-0.1} & osoba č. 1 & osoba č. 2 & osoba č. 3 & osoba č. 4 \\
\hline \multirow{2}{nyyyy}{\multicolumn{1}{c|}{}} & 0.57 & 0.655 & 0.635 & 0.51 \\
\hline klasická žárovka & 0.5 & 0.66 & 0.6 & 0.48 \\
\hline LED žárovka & 0.07 & -0.005 & 0.035 & 0.03 \\
\hline rozdíl & 0.166 & 0.166 & 0.166 & 0.166 \\
\hline
\end{tabular}

Obr. 6 Dílčí výsledky pro zhasnutá obrysová světla

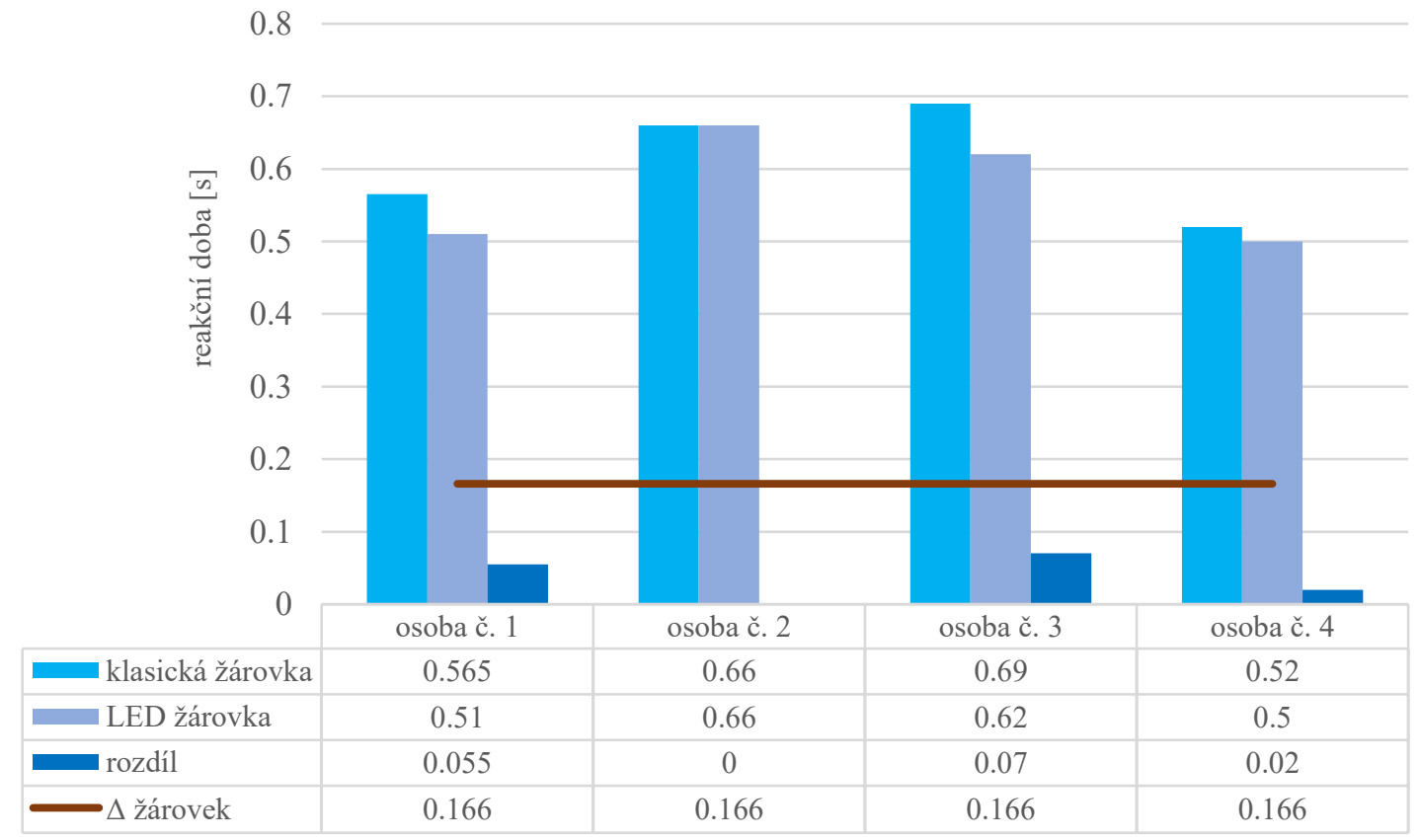

Obr. 7 Dílčí výsledky pro rozsvícená obrysová světla 


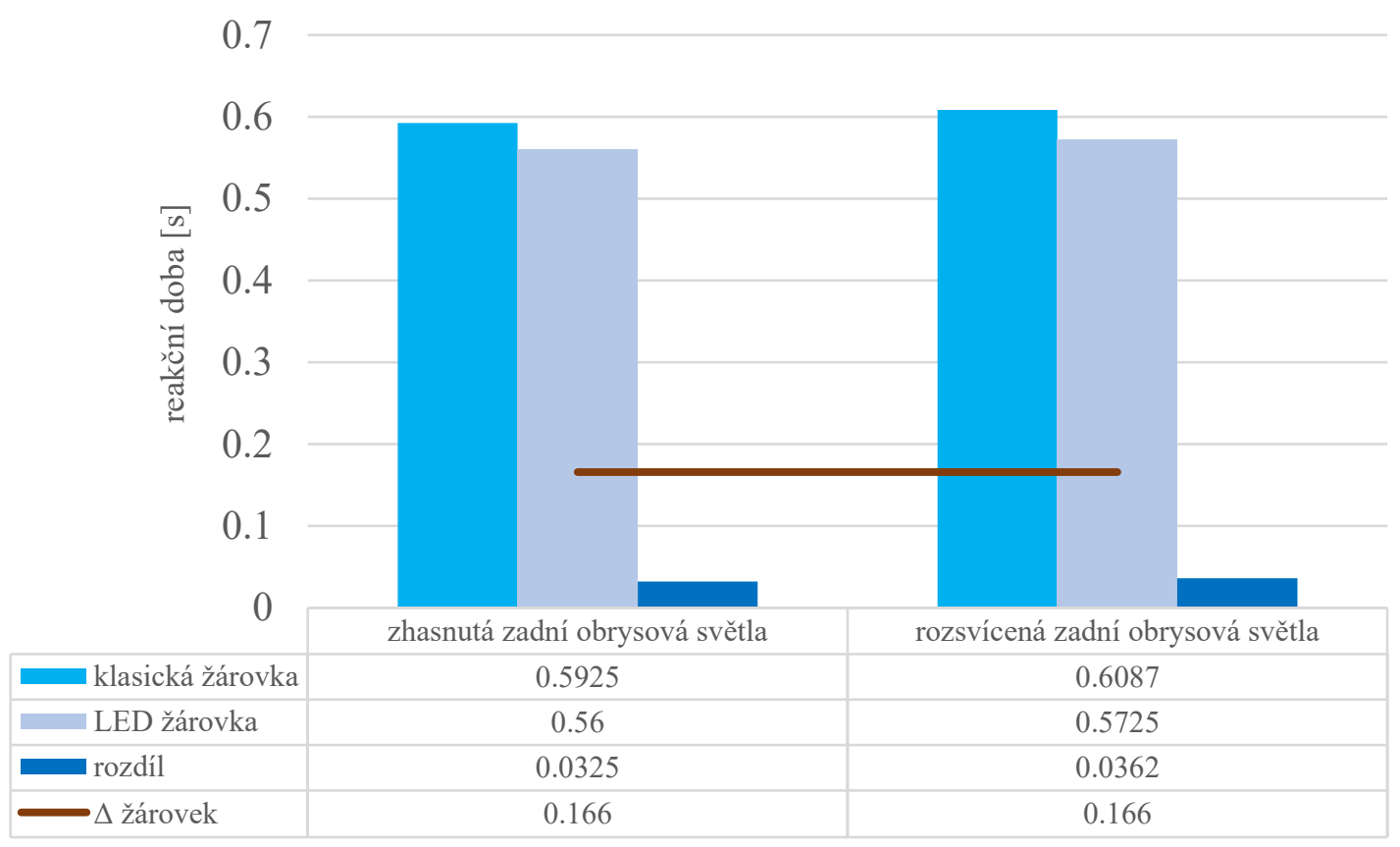

Obr. 8 Souhrnné výsledky

Největší zkrácení reakční doby u jednotlivce bylo 0,07 s, což odpovídá 42,17 \% očekávaného zkrácení reakční doby řidiče. Průměrné zkrácení reakční doby celé skupiny bylo 0,0344 s, což odpovídá 20,72 \% očekávaného zkrácení reakční doby řidiče. Na základě výsledků z experimentálního měření lze předpokládat, že lidské oko reaguje na klasickou žárovku již v průběhu jejího rozsvícení, a nikoliv až na její plný svit. Výsledky experimentu neprokázaly, že v případě nahrazení klasické žárovky LED žárovkou dojde ke zkrácení reakční doby o očekávaných 0,166 sekundy.

Z naměřených výsledků je patrné, že řidič jedoucí za vozidlem, které má instalované LED zdroj světla, začne při rychlosti $130 \mathrm{~km} \cdot \mathrm{h}^{-1}$ brzdit v průměru o 1,24 m dříve než při použití klasického zdroje světelného toku. $V$ př́padě naměřeného maxima u jednotlivé osoby dojde ke zkrácení brzdné dráhy až o 2,5 metru. Existuje předpoklad, že při užití homologovaného zdroje, který má vyšší světelný tok než námi použitý nehomologovaný LED zdroj, dojde ještě k dalšímu snížení reakční doby řidiče.

\section{ZÁVĚR}

Z experimentálního měření je patrné, že ke změně v reakční době došlo při použití LED světelného zdroje. Současně na délku reakční doby má vliv, zda jsou rozsvícena či nikoli zadní obrysová světla. Při rozsvícení brzdových světel při současném svitu obrysových světel je spouštěcí impuls méně kontrastní, proto je i reakční doba prodloužena. Při použití LED světelného zdroje došlo ke zkrácení reakční doby oproti klasickému zdroji světla. Jelikož testovaný řidič očekával v blízkém časovém intervalu vznik testovacího podnětu v podobě rozsvícení brzdových světel vodícího vozidla, je reakční doba psychické reakce řidiče zkrácena na minimum. Protože stejné podmínky testování byly pro všechny experimentální měření a výsledky se zpracovávají v relativní rovině a nikoli absolutní, tak toto zjednodušení nepůsobí znehodnocením výsledků experimentu.

Pro vyslovení exaktního závěru vycházejícího z výsledků experimentu je bezpodmínečně nutné, experimentální měření realizovat na reprezentativním a statisticky významném vzorku řidičů a současně v různých okolních podmínkách, případně při experimentální dynamické (jízdní) zkoušce. 


\section{Poděkování}

Příspěvek vznikl na základě podpory projektu SGS_2020_009 "Vybrané výzkumné problémy z oblasti dopravních prostředků a infrastruktury".

\section{Literatura}

Autorevue.cz. 2019. Systémy nočního vidění? Zatím exkluzivita. [online]. Czech News Center. Dostupné z: https://www.autorevue.cz/systemy-nocniho-videni-zatim-exkluzivita_1 [cit. 15.05.2020].

Autoforum.cz. 2019. Fordy chtějí svými brzdovými světly „svítit“i za zatáčku. [online]. MotorCom s.r.o. [cit. 06.04.2019]. Dostupné z: http://www.autoforum.cz/technika/fordy-chteji-svymi-brzdovymi-svetlysvitit-i-za-zatacku/ [cit. 21.04.2020].

Borecký, P. 2018. Reakční čas řidičů. Praha, Diplomová práce. České vysoké učení technické Praha.

Bradáč, A. 1997. Soudní inženýrství. Brno: Akademické nakladatelství CERM.

Jilek, P. 2018. Vývoj systému pro ověřování jízdní stability silničního vozidla ve vztahu kadhezním podmínkám, Dizertační práce. Univerzita Pardubice. Pardubice.

Kleprlík, J. 2020. Opatření pro zajištění účinného a správného brzdění silničních vozidel. Perner's Contacts, 11(1), 68-81.

Osmančík, R. 2017. Analýza změny reakční doby vlivem působení vnějších a vnitřních vlivů organizmu. Diplomová práce. VŠB - Technická univerzita.

Sorniotti, A. 2004. Hardware in the Loop for Braking Systems with Anti-lock Braking System and Electronic Stability Program, SAE Technical Paper 2004-01-2062.

Suzuki. 2019. Pokročilý systém sledování provozu před vozem. [online]. Auto Motors a.s. Dostupné z: http://www.automotors.cz/novy-suzuki-swift/bezpenost [cit. 06.04.2020].

Štěrba, P. 2013. Elektronika a elektrotechnika motorových vozidel: seřizování, diagnostika závad a chybové kódy $O B D$. CPress.

Vlk, F. 2006. Automobilová elektronika. Brno, Nakladatelství a vydavatelství Vlk.

Zikmund, T. 2006. Dynamika podvozkových částí silničních vozidel, Dizertační práce. Univerzita Pardubice. Pardubice. 